\title{
ANALISIS KESULITAN SISWA KELAS IV SEKOLAH DASAR DALAM MENYELESAIKAN SOAL PEMECAHAN MASALAH
}

\author{
Ummu Fauzi Saja'ah ${ }^{1}$ \\ Universitas Pendidikan Indonesia
}

\begin{abstract}
One of the goals of mathematical education is for students to have the ability to solve problems that include the ability to understand problems, design math models, complete the model and interpret the solutions obtained. So that students are expected to solve the problems that they encounter in their daily lives. However, difficulties can not be avoided when students are faced with the problems they encountered. The purpose of this study is to explain 1) Student difficulties in completing problem-solving question based on Polya's approach; 2) The cause of student difficulty in completing problem solving. Research method used is descriptive qualitative research method. The subject of this research is the fourth grade students in one elementary school in West Bandung Regency with a total of 30 students. Once analyzed, the results obtained are that students are having difficulty at 1) Determining the way in which the solution should be done to solve the problem; 2) Perform correct count operation 3) Conclude from result obtained.
\end{abstract}

Keyword: student difficulties, problem solving.

\begin{abstract}
Abstrak: Salah satu dari tujuan pendidikan matematika adalah agar siswa memiliki kemampuan untuk memecahkan masalah yang meliputi kemampuan memahami masalah, merancang model matematika, menyelesaikan model dan menafsirkan solusi yang diperoleh. Sehingga siswa diharapkan mampu menyelesaikan permasalahan yang ia temui dalam kehidupan sehari-hari. Namun, kesulitan-kesulitan tidak dapat dihindari ketika siswa dihadapkan pada persoalan yang ia temui. Tujuan dari penelitian ini adalah untuk menjelaskan 1) Kesulitan-kesulitan siswa dalam menyelesaikan soal pemecahan masalah berdasarkan langkah menurut Polya; 2) Penyebab kesulitan siswa dalam menyelesaikan soal pemecahan masalah. Metode penelitian yang digunakan adalah metode penelitian kualitatif deskriptif. Subjek dari penelitian ini adalah siswa kelas IV di salah satu SD di Kabupaten Bandung Barat dengan jumlah siswa 30 orang. Setelah dianalisis, hasil yang diperoleh bahwa siswa mengalami kesulitan pada 1) Menentukan cara penyelesaian yang seharusnya dilakukan untuk menyelesaikan soal tersebut; 2) Melakukan operasi hitung secara benar 3) Membuat kesimpulan dari hasil yang telah diperoleh.
\end{abstract}

Kata Kunci: Kesulitan siswa, pemecahan masalah

\section{PENDAHULUAN}

Dalam kurikulum di Indonesia, matematika merupakan salah satu bagian dari mata pelajaran yang diberikan untuk membekali siswa dengan kemampuan berpikir logis, analitis, sistematis, kritis, kreatif, dan kemampuan bekerja sama serta kemampuan pemecahaan masalah. Hal ini sesuai dengan tujuan mata pelajaran matematika dalam Kurikulum Tingkat Satuan Pendidikan (BNSP, 2006) yang menjelaskan bahwa pembelajaran matematika yang dilaksanakan di sekolah bertujuan agar siswa memiliki kemampuan : 1) Memahami konsep matematika, menjelaskan keterkaitan antar konsep dan mengaplikasikan konsep atau algoritma, secara luwes, akurat, efisien, dan tepat, dalam pemecahan masalah 2) Menggunakan penalaran pada pola dan sifat, melakukan manipulasi matematika dalam membuat generalisasi, menyusun bukti, atau menjelaskan gagasan dan pernyataan matematika 3) Memecahkan

${ }^{1}$ Universitas Pendidikan Indonesia, Email: ummufauzi $\underline{\text { lastudent.upi.edu }}$ 
masalah yang meliputi kemampuan memahami masalah, merancang model matematika, menyelesaikan model dan menafsirkan solusi yang diperoleh 4) Mengomunikasikan gagasan dengan simbol, tabel, diagram, atau media lain untuk memperjelas keadaan atau masalah 5) Memiliki sikap menghargai kegunaan matematika dalam kehidupan, yaitu memiliki rasa ingin tahu, perhatian, dan minat dalam mempelajari matematika, serta sikap ulet dan percaya diri dalam pemecahan masalah.

Sejalan dengan tujuan matematika yang telah diuraikan diatas, salah satu kemampuan yang diharapkan dapat dimiliki oleh siswa adalah kemampuan pemecahan masalah. Suherman (2003) menyebutkan "Pemecahan masalah merupakan hal yang sangat penting, karena dalam proses pembelajaran maupun penyelesaian, siswa dimungkinkan memperoleh pengalaman menggunakan pengetahuan serta keterampilan yang sudah dimiliki untuk diterapkan pada pemecahan masalah yang tidak rutin". Hal tersebut diperkuat dengan pendapat Holmes (Wardhani, 2010) yang menyebutkan mengenai latar belakang atau alasan seseorang perlu belajar memecahkan masalah matematika adalah adanya fakta dalam abad dua puluh satu ini bahwa orang yang mampu memecahkan masalah akan mampu memecahkan masalah hidup dengan produktif. Holmes menambahkan, orang yang terampil memecahkan masalah akan mampu berpacu dengan kebutuhan hidupnya, menjadi pekerja yang lebih produktif, dan memahami isu-isu kompleks yang berkaitan dengan masalah global.

Sesuai dengan pendapat diatas, maka kemampuan pemecahan masalah perlu diberikan sejak usia siswa sekolah dasar. Kemampuan pemecahan masalah yang diajarkan dapat menjadi keterampilan yang akan dibawa pada masalah-masalah keseharian siswa dalam membuat keputusan. Dengan demikian, kemampuan pemecahan masalah yang dimiliki diharapkan mampu membantu siswa dalam mengatasi permasalahan dihidupnya kelak. Kemampuan pemecahan masalah siswa meliputi kemampuan dalam membaca soal, memahami maksud soal, mampu menuliskan apa yang diketahui dan apa yang ditanyakan, mampu menentukan rumus-rumus yang akan digunakan, menghitung berdasarkan rumus atau melakukan operasi hitung secara akurat, dan kemampuan menemukan jawaban dengan benar. Kemampuan-kemampuan tersebut perlu dimiliki oleh setiap siswa.

Namun, beberapa kesalahan dapat dilakukan oleh siswa yang mengalami kesulitan dalam belajar matematika. Kesulitan siswa tersebut merupakan kesalahan dalam memahami soal, kesalahan dalam pengambilan keputusan atau menentukan cara penyelesaian dan kesalahan dalam melakukan perhitungan. Peneliti tertarik dan mencoba mengidentifikasi beberapa kesulitan yang dialami siswa terhadap soal pemecahan masalah. Dari hasil tes yang diberikan, selanjutnya dianalisis mengenai apa kesulitan-kesulitan yang dihadapi siswa dalam mengerjakan soal pemecahan masalah dengan mengacu pada strategi pemecahan masalah Polya. Berdasarkan uraian tadi, maka tujuan dari penelitian ini adalah untuk menjelaskan 1) kesulitankesulitan yang dialami siswa dalam menyelesaikan soal pemecahan masalah, 2) penyebab kesulitan siswa dalam menyelesaikan soal pemecahan masalah.

\section{TINJUAN PUSTAKA \\ Pemecahan Masalah}

Suatu masalah apabila diberikan kepada seorang anak dan anak tersebut langsung mengetahui bagaimana cara menyelesaikannya dengan benar, maka soal tersebut tidak dapat dikatakan sebagai masalah. Suatu permasalahan adalah keadaan yang mendorong seseorang untuk menyelesaikannya akan tetapi seseorang itu belum mengetahui secara langsung cara penyelesainnya maka itulah yang dikatakan sebagai suatu masalah. Ruseffendi (1991) mengemukakan bahwa suatu persoalan 
merupakan masalah bagi seseorang bila persoalan itu tidak dikenalnya, dan orang tersebut mempunyai keinginan untuk menyelesaikannya, terlepas apakah akhirnya sampai atau tidak kepada jawaban masalah tersebut.

Pemecahan masalah merupakan salah satu pendekatan dan juga sebagai tujuan dalam pembelajaran matematika. Menurut Branca (Susilawati, 2012) bahwa pemecahan masalah merupakan tujuan umum dalam pembelajaran matematika, bahkan sebagai jantungnya matematika artinya kemampuan pemecahan masalah merupakan kemampuan dasar dalam belajar matematika. Selain itu menurut NCTM pemecahan masalah mengandung tiga pengertian yaitu pemecahan masalah sebagai tujuan, sebagai proses dan sebagai keterampilan.

Polya

(Suherman,

2012)

mendefinisikan bahwa pemecahan masalah merupakan suatu usaha mencari jalan keluar dari suatu kesulitan guna mencapai suatu tujuan yang tidak begitu mudah segera dapat dicapai. Pemecahan masalah adalah kemampuan siswa dalam memahami dan berfikir untuk mencari jalan penyelesainnya. Pemecahan masalah tersebut adalah meliputi kemampuan memahami masalah, merancang model matematika, menyelesaikan model dan menafsirkan solusi yang diperoleh. Jadi, pemecahan masalah adalah mencari carametode melalui kegiatan mengamati, memahami, mencoba, menduga, menemukan, dan meninjau kembali. Polya (Suherman, 2012) berpendapat bahwa tahapan memecahkan masalah adalah sebagai berikut:

a. Memahami masalah

Memahami masalah meliputi : memahami dan mengidentifikasi apa fakta atau informasi yang diberikan, apa yang ditanyakan, diminta untuk dicari, atau dibuktikan. Sering sekali siswa gagal dalam menyelesaikan soal karena siswa tidak paham akan masalah yang disajikan.

b. Memilih pendekatan atau strategi pemecahan
Merencanakan penyelesaian masalah dapat berupa misalkan menggambarkan masalah dalam bentuk diagram, memilih dan menggunakan pengetahuan aljabar yang diketahui dan konsep yang relevan untuk membentuk model atau kalimat matematika. Kemampuan melakukan langkah kedua ini tergantung pada pengalaman siswa yang bervariasi dalam menyelesaikan masalah seperti siswa pernah menemukan soal ini sebelumnya atau soal serupa dengan bentuk lain.

c. Menyelesaikan rencana penyelesaian

Menyelesaikan rencana penyelesaian adalah melakukan operasi hitung secara benar dalam menerapkan strategi untuk mendapatkan solusi dari masalah. Langkah ini menekankan pada pelaksanaan prosedur yang ditempuh. Pada langkah ini siswa dituntut ketelitian dan ketekunan agar mampu melakukan operasi hitung dengan benar jika tidak maka hasil yang diperoleh akan salah.

d. Mengecek kembali

Langkah ini menekanan pada bagaimana cara memeriksa kebenaran jawaban yang diperoleh meliputi memperkirakan dan memeriksa kebenaran jawaban, masuk akalnya jawaban, dan apakah memberikan pemecahan terhadap masalah semula serta memberikan alternatif cara lain dalam menyelesaikan soal.

\section{Kesulitan Belajar}

Wood (2007) menjelaskan beberapa karakteristik kesulitan belajar yang dialami siswa ketika belajar matematika yaitu 1) kesulitan membedakan angka, simbolsimbol, dan bangun ruang, 2) tidak bisa mengingat dalil-dalil matematika, 3) menulis angka dalam ukuran kecil, 4) tidak memahami simbol-simbol matematika, 5) lemahnya kemampuan berpikir abstrak, 6) lemahnya kemampuan metakognisi (kemampuan mengidentifikasi serta memanfaatkan algoritma dalam memecahkan soal matematika). Sementara Wood (2011) membagi kesulitan belajar menjadi tiga kategori besar, yaitu 1) 
kesulitan dalam berbicara dan berbahasa, 2) permasalahan dalam hal kemampuan akademik, 3) kesulitan lainnya yang mencakup kesulitan dalam mengoordinasi gerakan anggota tubuh.

Kesulitan berbahasa berkaitan dengan keterlambatan siswa dalam hal pemahaman bahasa. Sebagaian siswa menemui kendala dalam mencerna apa yang diucapkan maupun yang tertulis dalam bentuk kalimat-kalimat. Permasalahan dalam hal kemampuan akademik salah satunya meliputi keterlambatan dalam hal berhitung. Berhitung melibatkan angkaangka, pemahaman berbagai simbol matematis. Masalah yang berhubungan dengan matematika yang baru terjadi pada kelas-kelas tinggi yang lebih sering berkaitan dengan logika.

\section{METODOLOGI PENELITIAN}

Metode penelitian merupakan cara yang digunakan peneliti untuk mengumpulkan data secara objektif. Penelitian ini menggunakan penelitian kualitatif deskriptif dengan mengumpulkan data dari hasil tes yang diberikan kepada 30 siswa kelas IV di sebuah sekolah dasar di Kabupaten Bandung Barat. Kemudian data tersebut digambarkan melalui kata-kata atau uraian deskriptif untuk mengidentifikasi kesulitan anak dalam menyelesaikan soal pemecahan masalah.

\section{HASIL PENELITIAN DAN PEMBAHASAN}

Dari hasil tes yang diperoleh siswa dalam menjawab soal pemecahan masalah, peneliti menganalisis setiap butir soal sesuai dengan indikator dari langkah pemecahan masalah menurut Polya dan mengidentifikasi kesulitan-kesulitan yang dialami siswa, apa yang menjadi penyebab siswa salah dalam menjawab soal tersebut.

\section{Soal nomor 1}

Sebuah Truk A berhenti setelah berjalan $90 \mathrm{~km}$. Truk B berhenti setelah berjalan $120 \mathrm{~km}$. Jika kedua Truk berangkat pada tempat dan waktu yang sama, pada kilometer berapakah Truk A dan Truk B berhenti bersama-sama?

Jawaban yang diharapkan : KPK 90 dan $120=360$

Truk A dan Truk B akan berhenti pada kilometer 360

Jawaban yang muncul dari siswa :

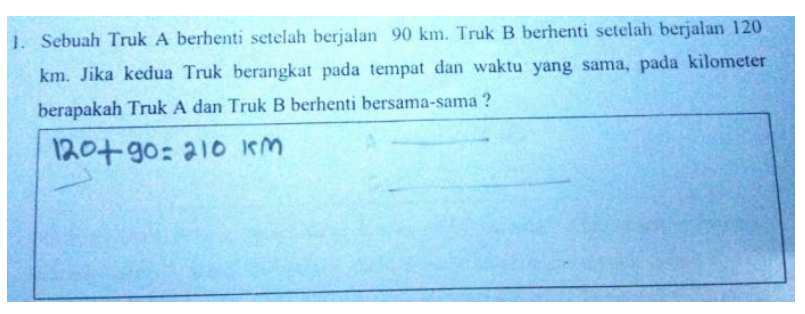

Gambar 1.1

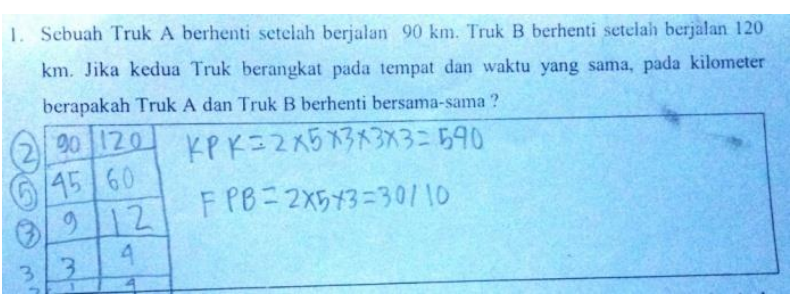

Gambar 1.2

Kesulitan-kesulitan yang dialami siswa dalam menjawab soal nomor 1 adalah

1. Siswa tidak memahami kalimat yang terdapat dalam soal. Siswa tidak mengerti maksud yang diinginkan dari pertanyaan tersebut.

2. Siswa mungkin lupa bagaimana menentukan KPK dan FPB dengan metode atau cara sisir seperti yang terlihat pada gambar 2 sehingga salah dalam menentukan KPK maupun FPB.

3. Siswa salah dalam melakukan perhitungan.

Sebagian besar siswa menjawab soal nomor 1 dengan salah dalam menentukan cara penyelesaian dan menjawab operasi hitung dengan benar. Hal tersebut dapat disebabkan oleh kemampuan siswa dalam mengubah soal cerita menjadi kalimat matematika masih rendah, kemampuan dasar yang harus dimiliki siswa seperti memahami konsep penjumlahan dan perkalian juga masih kurang serta ketelitian dalam melakukan operasi hitung masih kurang. Pada soal 
nomor 1 ini peneliti bermaksud untuk melihat indikator pada langkah terakhir tahapan pemecahan masalah yaitu memeriksa kembali jawaban dengan mencari alternatif cara lain yang dapat digunakan dalam menjawab soal nomor 1 . Namun, ada satu orang siswa yang dapat

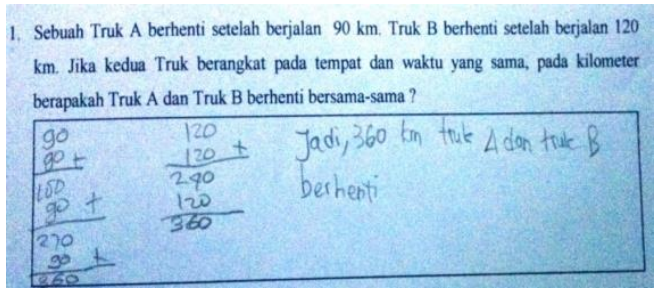

menjawab dengan alternatif lain selain menggunakan cara KPK yaitu dengan penjumlahan seperti tampak pada jawaban berikut ini:

\section{Gambar 1.3}

\section{Soal nomor 2}

Ibu ingin membagikan buah apel sebanyak 30 buah, jeruk sebanyak 32 buah, dan mangga sebanyak 48 buah kepada saudara-saudaranya dalam bentuk bingkisan. Setiap saudara mendapat jumlah buah sama banyak.

a) Berapa banyak saudara yang mendapat bingkisan dari Ibu?

b) Berapa banyak masingmasing buah yang diterima oleh saudara Ibu?

Jawaban yang diharapkan :

a) $\quad$ FPB dari 30,32 dan $48=2$, jadi saudara yang mendapat bingkisan dari ibu 2 orang

b) Apel : $30: 2=15$ buah

Jeruk : $32: 2=16$ buah

Mangga $: 48: 2=24$ buah

Jadi, masing-masing saudara ibu dapat 15 buah apel, 16 buah jeruk dan 24 buah mangga.

Jawaban yang muncul dari siswa :

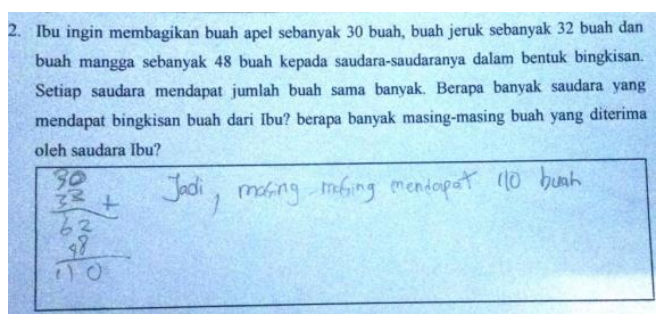

Gambar 2.1

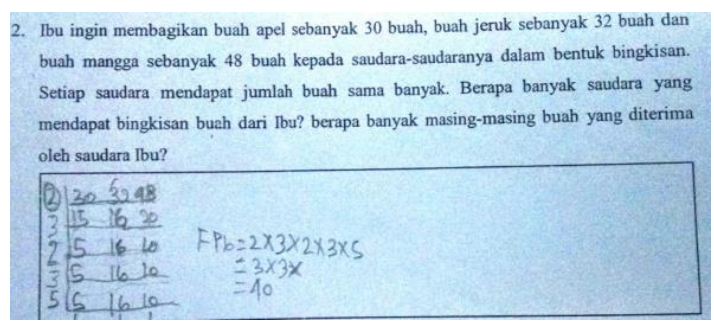

\section{Gambar 2.2}

Kesulitan-kesulitan siswa dalam menjawab soal nomor 2 adalah :

1. Siswa tidak memahami maksud dari pertanyaan, apa yang ditanyakan dari soal tersebut, apa yang diminta untuk dicari jawabannya.

2. Siswa salah menentukan FPB dan salah melakukan operasi hitung dengan benar.

Sebagian siswa sudah benar dalam menjawab soal nomor 2, beberapa siswa belum bisa menjawab dengan tepat karena kendalanya pada menentukan FPB dan melakukan operasi hitung dengan benar. Hal itu disebabkan oleh siswa mungkin lupa bagaimana menentukan FPB, siswa tidak teliti dalam melakukan operasi hitung perkalian. Siswa tidak mencoba mencari FPB dengan menggunakan pohon faktor, banyak siswa yang menggunakan cara seperti pada gambar 2.2. Pada soal nomor 2 ini peneliti bermaksud untuk melihat apakah siswa dapat menjalankan operasi hitung dengan benar sesuai dengan langkah pemecahan masalah yang ketiga yaitu penyelesaian cara atau strategi yang telah direncanakan. Sebagian siswa sudah benar dalam melakukan operasi hitung namun sebgaian lagi masih keliru dalam melakukan operasi hitung.

\section{Soal nomor 3}

Disebuah Desa sedang mengadakan lomba makan kerupuk. Anto dapat memakan 6 kerupuk dalam 3 menit. Sedangkan Badu dapat memakan 3 kerupuk dalam 6 menit. Berapa kerupuk yang dapat 
mereka makan secara bersama-sama dalam waktu 18 menit?

Jawaban yang diharapkan: Dapat diselesaikan dengan mencari kelipatan

\begin{tabular}{|l|l|l|l|l|l|l|l|}
\hline Anto & Waktu & 3 & 6 & 9 & 12 & 15 & 18 \\
\hline & Kerupuk & 6 & 12 & 18 & 24 & 30 & $\mathbf{3 6}$ \\
\hline Badu & Waktu & 6 & 12 & 18 & & & \\
\hline & Kerupuk & 3 & 6 & $\mathbf{9}$ & & & \\
\hline
\end{tabular}

Anto selama 18 menit memakan kerupuk sebanyak 36

Badu selama 18 menit memakan kerupuk sebanyak 9

jadi mereka makan kerupuk secara bersama-sama sebanyak 45 kerupuk

Jawaban yang muncul dari siswa adalah :

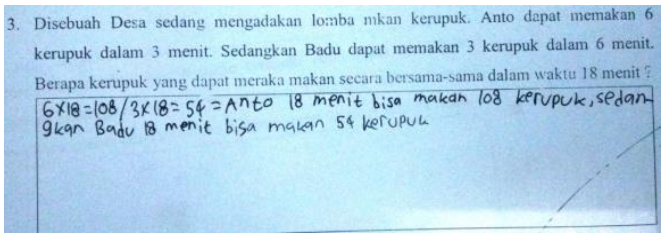

Gambar 3.1

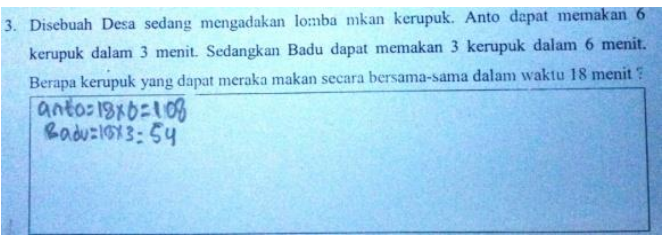

Gambar 3.2

Kesulitan-kesulitan siswa dalam menjawab soal nomor 3 adalah:

1. Siswa tidak memahami kalimat matematika yang terdapat dalam soal.

2. Siswa tidak memahami konsep kelipatan

3. Siswa kebingungan dalam mencari cara menyelesaikan soal tersebut.

Beberapa siswa dapat menjawab soal ini dengan tepat, namun sebagian siswa masih salah dalam menjawab soal ini. Hal ini disebabkan karena siswa mungkin lupa dengan konsep kelipatan yang telah diajarkan, kemampuan memahami bahasa dalam soal masih rendah, pengalaman siswa dalam mengerjakan soal seperti ini masih minim. Pada soal nomor 3 ini peneliti bermaksud melihat cara atau strategi yang digunakan sesuai dengan langkah pemecahan masalah yang kedua yaitu merencanakan strategi penyelesaian. Beberapa siswa tepat dalam melakukan strategi penyelesaian. Namun, masih banyak siswa yang keliru dalam memilih strategi penyelesaian seperti yang terlihat pada gambar 3.1 dan gambar 3.2.

\section{Soal nomor 4}

Disebuah kandang terdapat 10 kepala bebek dan sapi. Jumlah kaki bebek dan sapi itu ada 30. Berapa banyak bebek dan berapa banyak sapi yang ada di kandang itu?

Jawaban yang diharapkan : 5 ekor sapi dan 5 ekor bebek

Jawaban yang muncul dari siswa :

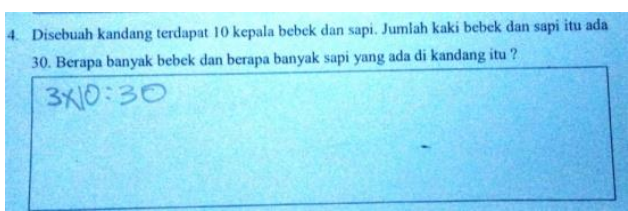

\section{Gambar 4.1}

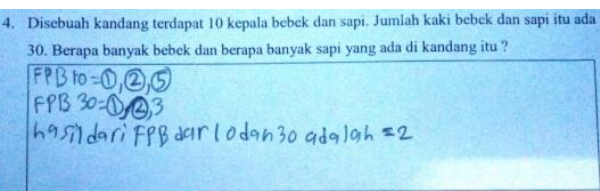

Gambar 4.2

Kesulitan-kesulitan siswa dalam menjalankan soal nomor 4 adalah siswa tidak memahami apa yang ditanyakan, apa yang diminta untuk dicari jawabannya dari soal. Siswa tidak mengerti kalimat matematika yang terdapat dalam soal.

Siswa mungkin lupa mengaitkan konsep kehidupan nyata kedalam pembelajaran seperti terlihat dari jawaban siswa berikut ini :

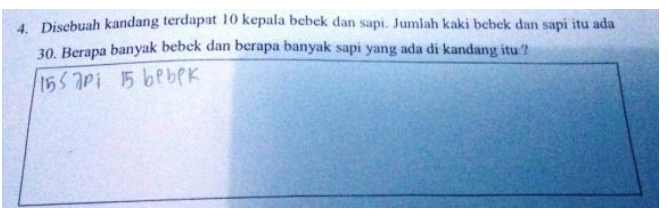

Gambar 4.3

Siswa lupa bahwa bebek memiliki 2 kaki sementara sapi memiliki 4 kaki. Dengan memperhatikan itu siswa akan mudah menjawab soal nomor 4. Beberapa 
siswa dapat menjawab soal ini dengan benar. Namun, siswa yang lain masih salah dan kebingungan dalam menjawab soal terakhir ini. Pada soal ini peneliti ingin melihat apakah siswa memahami masalah yang disajikan dalam soal dan melihat apakah jawaban yang diberikan masuk akal atau tidak berdasarkan pertanyaan yang diberikan. Tetapi melihat jawaban yang ada masih banyak siswa yang belum bisa menyelesaikan soal nomor 4 ini. Hal ini disebabkan siswa tidak mampu bernalar dengan baik, siswa terbiasa menggunakan cara atau strategi yang telah dipelajari sehingga siswa tak bisa mencari cara atau strategi lain.

\section{KESIMPULAN}

Berdasarkan analisis tes soal pemecahan masalah dan pembahasan menunjukkan bahwa kesulitan-kesulitan siswa dalam menyelesaikan soal pemecahan masalah berdasarkan langkah Polya sebagian besar adalah dalam hal 1) memahami maksud kalimat dari soal yang diberikan. Siswa tidak memahami apa yang ditanyakan, 2) menentukan cara atau strategi penyelesaian yang seharusnya dilakukan. Siswa masih keliru dalam menggunakan strategi peyelesaian, seperti seharusnya menggunakan cara FPB tetapi siswa menyelesaikan dengan cara penjumlahan, 3) melakukan operasi hitung secara benar. Penyebab siswa mengalami kesulitan tadi adalah sebagai berikut 1) siswa tidak mengerti bahasa dalam kalimat sehingga siswa tidak tahu maksud dari soal yang diberikan oleh karena itu siswa salah menentukan cara penyelesaian. Siswa sulit mengubah dari soal cerita menjadi kalimat matematika, 2) kurangnya penguasaan berbagai strategi dalam menyelesaikan soal-soal, 3) siswa tidak terbiasa untuk menyelesaikan soal pemecahan masalah sehingga ketika dihadapkan pada persoalan tersebut siswa tidak bisa menjawab dengan tepat, 4) kurangnya ketelitian dan kehatihatian dalam melakukan operasi hitung sehingga siswa masih salah dalam menjalankan dan menjawab soal. Siswa tidak memahami konsep penjumlahan, perkalian, dan pembagian.

Adapun saran yang dapat disampaikan setelah melakukan penelitian ini yaitu 1) dalam pembelajaran hendaknya guru menggunakan berbagai metode atau model pembelajaran yang merangsang siswa untuk dapat memecahkan masalah, lebih penting siswa agar memahami konsep matematika terlebih dahulu 2) guru memberikan bantuan kepada siswa yang mengalami kesulitan dengan menggunakan teknik scafolding, yaitu memberikan bantuan secara bertahap sampai siswa mampu mengerjakan tugas secara mandiri, 3) siswa perlu diberikan latihan-latihan pemecahan masalah sehingga siswa menjadi terbiasa dengan soal-soal tersebut

\section{DAFTAR PUSTAKA}

BNSP. (2006). Kurikulum Tingkat Satuan Pendidikan. Jakarta: Dirjen

Ruseffendi, E. T. (1991). Penilaian Pendidikan dan Hasil Belajar Siswa Khususnya dalam Pengajaran Matematika untuk Guru dan Calon Guru. Bandung: Diktat.

Suherman, E. (2003). Strategi Pembelajaran Matematika Kontemporer. Bandung: Balai Percetakan dan Penerbitan UPI

Suherman, E. (2012). Belajar dan Pembelajaran Matematika. Bandung: Balai Percetakan dan Penerbitan UPI

Susilawati, W \& Anita. (2012). Modelmodel Pembelajaran Inovatif. Bandung: Universitas Islam Negeri Sunan Gunung Djati

Wardhani, Sri, dkk. (2010). Pembelajaran Kemampuan Pemecahan Masalah Matematika di SD. Yogyakarta: Kemendiknas Dirjen Peningkatan Mutu Pendidik dan Tenaga Kependidikan; (PPPPTK) Matematika.

Wood, D.R. (2007). Professional Learning Communities: Teachers, Knowledge, and Knowing Theory into Practice, 46(4), 281-290

Wood, D, dkk. (2011). Kiat Mengatasi Gangguan Belajar.Yogyakarta: Katahati 